\title{
FLEXIBLE WORKING IN SCOTTISH LOCAL AUTHORITY PROPERTY: MOVING ON TO THE HIGHEST FLEXIBILITY LEVEL
}

\author{
Thadsin KHAMKANYA ${ }^{1}$ and Brian SLOAN $2 \bowtie$ \\ 1 School of Engineering and the Built Environment, Edinburgh Napier University, \\ 10 Colinton Road, Edinburgh, Scotland EH10 5DT, UK \\ E-mail: t.khamkanya@napier.ac.uk \\ 2 School of Engineering and the Built Environment, Edinburgh Napier University, \\ 10 Colinton Road, Edinburgh, Scotland EH10 5DT, UK \\ E-mail: B.Sloan@napier.ac.uk
}

Received 18 December 2008; accepted 9 February 2009

\begin{abstract}
Flexible working has emerged as a modern concept for managing office resources more effectively, efficiently, and economically. The highest level of flexible working environment, a non-territorial working environment, can provide the best opportunity to an organisation managing its office area more effectively. Moreover, staff can work in the most suitable place and time. However, in the context of public offices like Scottish Local Authorities, the most flexible working concept is not particularly welcomed at present. Cultural change, inadequate support services, including information and communication technology, working schemes, and alternative working policies are the main barriers. To overcome these barriers, the Authorities need to strategically provide adequate support to staff. Moreover, promoting a good perception towards flexible working culture at appropriate levels within an organisation could be the right strategy for preventing cultural change problems.
\end{abstract}

KEYWORDS: Flexible Working; Non-territorial Working Environment; Scottish Local Authority; Property

\section{INTRODUCTION}

Efficiency, Effectiveness and Economics (3Es) in property management have been recommended by both researchers and, particularly, Government auditors. The Audit Commission (AC) (1988a, 1988b) recommended property management of Local Authorities (LAs) to prepare strategic operational cost information and adequate property review. The main reason was that strategic property management information could enable senior management to achieve better efficiency, effectiveness and economy of property management (Gibson and
Hedley, 1999). Modern office initiatives, such as open-plan, hotdesking, and flexible working hours have been introduced as modern property management tools (Audit Commission, 2000).

Gershon (2004) and Lyons (2004) identify the broad objectives of public sector efficiency. These are: 1) reduce resource costs, not public services; 2) enhance quality and quantity of production; and 3) improve the ratio of output per unit cost of input. In their opinion to achieve these objectives, LAs should:

- Increase the level of investment in ICT in both central and local Government; 
- Develop a HR joined-up approach facilitating back office functions;

- Share back offices both within and between LAs.

The issues addressed above show that senior management should consider employing the modern concept of office management, especially flexible working, as a tool for achieving better $3 \mathrm{Es}$ of property management (Gibson and Luck, 2004). To understand the relationship between flexible working and property management, the development of flexible working is described as a fundamental principle.

\section{LITERATURE REVIEW}

\subsection{Development of flexible working}

\subsubsection{Information and Communication Technology}

Since the 1990s, Information and Communication Technology (ICT) has been introduced to organisations to provide benefits, in terms of efficiency and effectiveness, to property management practice (Kirkwood, 1994; 1995). For example, the number of paper documents has been reduced since electronic documents were introduced. An effective ICT working environment has been identified as below (Rowlatt et al., 2002; Dixon, 2005):

- Computer mediated network should be an essential infrastructure for assembling, analysing, communicating, and managing information;

- Both internal and external information transactions are able to proceed through Electronic Data Interchange (EDI) or over the internet;

- Added value could be obtained from interactive information transfer between organisations or individuals.

According to Hurme (2005), ICT systems in modern offices can be categorised into two groups, which are wired and wireless system. A wired ICT system includes, for example, broadband internet, local intranet, and Voice over Internet Protocol (VoIP). A wireless ICT system includes, for example, wireless network and Bluetooth.

An increase in demand for modern ICT services was shown in Gibson and Luck's longitudinal survey on Corporate Real Estate (CRE) practice (Gibson and Luck, 2006). The research indicates that the modern working environment, supported by modern ICT applications, has been increasingly demanded by organisations (ibid). The development significantly impacts the current corporate working environment, in terms of, mobility, networkability, and implied productivity (Sullivan, 1996; Dixon, 2005).

\subsubsection{Workspace management}

Impacts of modern ICT (broadband, wireless, etc.) and management concepts (hotdesking, flexitime working hours, etc.) influence the working styles of people from a static to a dynamic style (Dettwiler, 2008). Much office workspace has been changed from a traditional layout (arranged by group of functions) to a modern layout (arranged by activity objective) (McGregor, 2000). Current workspace management concepts include work-space and portfolio flexibility models (Laing et al., 1998; Nenonen, 2004; Ward and Holtham, 2000; Gibson and Lizieri, 1999). Recently, these models were combined for enabling an organisation to manage its workspace more effectively on the basis of activity-based and financial flexibility (Khamkanya and Sloan, 2008). As shown in Figure 1, the model may assist an organisation to 1) match the workspace to the activities of staff, and 2) promote financial flexibility in the organisation area.

\subsubsection{Human resource}

Since business policies have been regularly influenced by changes of technology, customer's needs, and corporate efficiency plans, workers are inevitably pressured by the business environment to work longer than regular working hours (DfEE, 2000). The experiences of long 


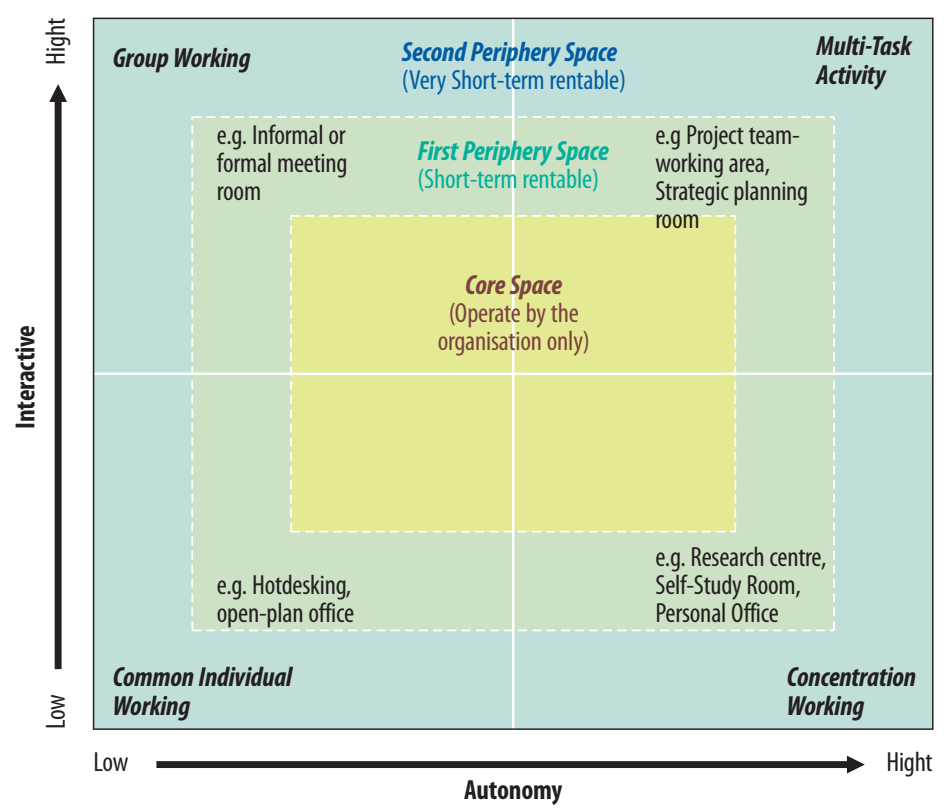

Figure 1. Combination of workspace-portfolio flexibility models Source: Khamkanya and Sloan (2008)

hours and intense working may negatively affect workers' health, psychological well-being and family life (Burchell et al., 1999). The working efficiency of the individual may drop, and the number of absentees may increase. These may bring about a high turn-over rate and a reduction in organisational performance. In particular, when losing valuable human resources, organisations have to invest in new ones with costly training (DfEE, 2000).

To solve the above problems, flexible working concepts such as Work-Life Balance (WLB) and Family Friendly Policy (FFP) should be adopted in modern offices (Clark, 2000; Ackers, 2003). In practice, alternative working schemes may include flexitime, compressed hours, annualised hours, shift-swapping, selfrostering, short-period break and long-term absence (DfEE, 2000).

\subsection{Evolution stages of flexible working}

According to Gibson and Luck (2004), as shown in Figure 2, five evolution stages of flexible working are described (NAO, 2006; Gibson and Luck, 2004; Gibson, 2003):
Stage 1 - Traditional working environment (e.g. cellular office) is used. Availability of shared equipment is very limited. Staff work within an organisation's premises.

Stage 2 - Shared-office environment (e.g. hotdesking and open-plan working area) can be found. Staff can relocate within a limited area. Data can be electronically transferred via wired ICT network.

Stage 3 - Informal support (e.g. breakout areas or informal meeting rooms) are provided for staff. More types of activity-based working areas can be seen in the office. Electronic data can be transferred from a distance. Various working-time schemes (e.g. flexitime, compressed hours, and annualised hours) may provide to staff.

Stage 4 - Flexible working environment is generally available for staff. Staff may work anywhere within the office. Wireless ICT system may be provided in some working areas. Staff can work from distant offices under controlled environment security system. 


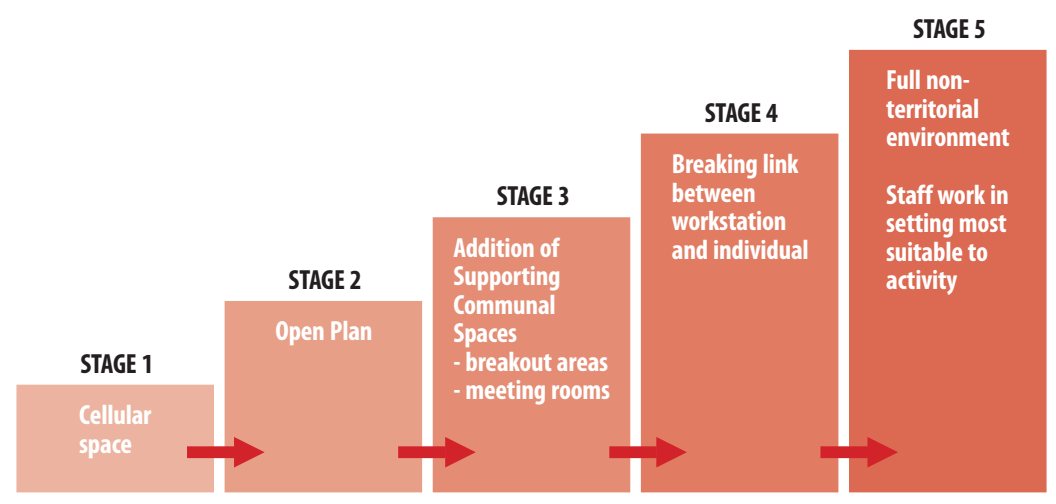

Figure 2. Evolution stages of flexible working Source: Gibson and Luck (2004)

Stage 5 - Staff may work anywhere in flexible time. Wired- and wireless access points are provided in most organisation area. Staff may work under a self-rostering scheme. An organisation may promote concepts of space sharing and very short-term letting.

\subsection{Scottish local authority - flexible working}

The adoption of flexible working has been discussed as a suitable concept for managing the modern office environment (NAO, 2006). The benefits of adopting flexible working appear in several organisations. For example, Work-Life Balance can be effectively achieved, and working atmosphere has been improved (ibid). Although organisations adopting flexible working may receive positive outcomes, the success of flexible working adoption in one organisation cannot guarantee that other organisations will obtain the same results. Scottish Local Authorities (SLAs) are organisations having unique characteristics regarding their management system, including ICT, HR, and workspace management. Consequently, the working environment of SLAs may vary from place to place and by size. To find out whether or not the highest flexible working stage can be practically adopted in SLA, information on alternative working policies, ICT services and flexible working schemes will be investigated.

\section{RESEARCH METHODOLOGY}

The research has as its main question to understand flexible working practice in Scottish Local Authorities (SLAs). In particular:

- How could SLAs move on to the highest flexible working environment?

- What are the possible benefits/problems concerned with the highest flexible working environment?

Objectives of the research are:

- To elicit the opinion of SLA staff towards the highest flexible working environment adoption, in terms of potential benefits and barriers, and how to measure the level of working flexibility of staff;

- To elicit the opinion of SLA staff towards the flexible working applications, in terms of ICT, HR and workspace management;

- To propose guidelines to assist SLAs to successfully promote and adopt flexible working in practice.

The research aims to acquire information from middle management working in ICT, $\mathrm{HR}$, and property/estate/facility management of SLAs. The invited participants are experienced staff who would be able to respond to the specific research questions in-depth from their broad experience. These include, for example, 
property managers, senior estate officers, facility managers, ICT managers, personnel managers, and human resource managers. The selected participants are expected to reflect the current SLA's policy direction and demands of subordinates regarding their flexible-working environment (Bryman, 2004).

Since the SLAs are scattered throughout Scotland, a postal questionnaire survey was selected as the most suitable survey method for the research (Fink, 2006). In the questionnaire, there were a number of structured questions. Data from the structured questions was used in numerical and categorical analysis and interpretation (Dawson, 2006).

After the questionnaire was prepared, a pilot test was undertaken with the City of Edinburgh Council staff. After the pilot test was completed, there were some amendments, particularly inappropriate language, difficult questions, unclear statements, too many ranking choices, and vague wording. Benefits of pilot testing and questionnaire amendment include reducing vague questions, adjusting questionnaire structure, reducing difficulty of questionnaire and increasing the applicability of the questionnaire (Dillman et al., 2002).

According to the preliminary interviews during the pilot test, some management staff argue that the flexible working concept may not be properly understood as the modern concept of property management of SLAs, because flexible working is currently only promoted as a tool by HR.

\section{SURVEY RESULT}

Out of 100 invited participants, 21\% returned completed questionnaires. $8 \%$ of respondents sent back blank questionnaires and a letter indicating that they could not respond to the survey. Reasons for non-completion included that they did not have specific informa- tion or experience regarding flexible working practice in their SLAs. The survey results are presented below.

\subsection{Opinion towards 'Non-territorial' working environment}

According to the open-ended question of 'non-territorial' working environment' - "If all workstations in your department are becoming shared resources and nobody has a permanent workstation, how would this situation affect your department's performance?" respondents have provided interesting opinions, both positive and negative. For example: one manager stated that "If people do share desktop PCs, I am not sure this would affect performance". Another stated that "It's the desk and the space they want to own"; yet another stated that "People would adjust in time but at first there would be problems and discontent". However, there are some opposite opinions, for instance, "In time, the department's performance would be as good even though the cost of inputs (property) would be less", "Would probably improve", and "Although there are no permanent workstations, resources are shared and available to allow staff to fulfil their roles".

All open-ended opinions were transformed and categorised into two groups, which are repeated benefits and barriers. According to the most repeated benefits, a small number of staff recognised 'staff satisfaction', 'better organisational culture', and 'better work performance' as possible positive outcomes where the organisation moves on to the highest level of flexible working practice.

According to the barriers, three major barriers are presented in Table 1 . Some respondents $(30 \%)$ state that the 'non-territorial environment' may lead to staff resistance and cultural change challenge problems. Moreover, $15 \%$ of respondents state that unsuitable management system may have an effect on the scheme. 
Table 1. Stated potential problems from 'Non-territorial working environment'

\begin{tabular}{|c|c|c|c|c|c|c|}
\hline \multirow[t]{2}{*}{ Potential problems } & \multicolumn{2}{|c|}{ Not stated } & \multicolumn{2}{|l|}{ Stated } & \multicolumn{2}{|l|}{ Total } \\
\hline & Count & $\%$ & Count & $\%$ & Count & $\%$ \\
\hline Staff resistance & 14 & $70.0 \%$ & 6 & $30.0 \%$ & 20 & $100.0 \%$ \\
\hline Cultural change challenge & 14 & $70.0 \%$ & 6 & $30.0 \%$ & 20 & $100.0 \%$ \\
\hline Unsuitable management system & 17 & $85.0 \%$ & 3 & $15.0 \%$ & 20 & $100.0 \%$ \\
\hline
\end{tabular}

\subsection{Opinion towards monitoring flexible working staff}

According to the open-ended question of monitoring flexible working staff - "If your staff are allowed to work from anywhere and anytime, how would you control and monitor their working performance?", respondents have provided interesting opinions based on their direct and indirect experience. For example: one manager stated "Introduce performance indicator that show when staff have completed tasks". Another stated that "Yet to be considered within council but personally I would propose output performance monitoring"; yet another stated that "Work plans and targets would assist; flexible working by its very nature allows staff to work at times that suit them".

Respondents' attitude towards monitoring flexible working staff is presented in Table 2 . $80 \%$ of respondents propose a measurable target and output as a main measure for monitoring flexible working staff. $40 \%$ of respondents believe that there should be a working-time tracking system supporting the monitoring of flexible working staff. The remaining meas- ures infrequently stated by respondents are trust based working (20\%) and occasional meeting (15\%).

\subsection{Adoptability degree of flexible working schemes}

Further analysis regarding the application of flexible working was undertaken in particular management areas. According to the HR management area, the respondents were asked to indicate how a particular flexible working scheme has been adopted at present. The degree of adoption may indicate how SLA officers support the adoption of flexible working schemes in practice. As shown in Table 3, there are several types of flexible working schemes, including flexitime working, compressed hours short-period break, longer absence, annualised hours, shift swapping, and self-rostering. The degree of adoptability, which respondents have given, is indicated on a scale of 1-5 as [1] a scheme is hard to adopt, [2] a scheme is slightly hard to adopt, [3] a scheme is not hard or easy to adopt, [4] a scheme is slightly easy to adopt, and [5] a scheme is easy to adopt.

Table 2. Stated measures from Open-ended opinion

\begin{tabular}{|c|c|c|c|c|c|c|}
\hline \multirow[t]{2}{*}{ Proposed measures } & \multicolumn{2}{|c|}{ Not Stated } & \multicolumn{2}{|l|}{ Stated } & \multicolumn{2}{|l|}{ Total } \\
\hline & Count & $\%$ & Count & $\%$ & Count & $\%$ \\
\hline Measurable target and output & 4 & $20.0 \%$ & 16 & $80.0 \%$ & 20 & $100.0 \%$ \\
\hline Working-time tracking system & 12 & $60.0 \%$ & 8 & $40.0 \%$ & 20 & $100.0 \%$ \\
\hline Trust based working & 16 & $80.0 \%$ & 4 & $20.0 \%$ & 20 & $100.0 \%$ \\
\hline Occasional meeting & 17 & $85.0 \%$ & 3 & $15.0 \%$ & 20 & $100.0 \%$ \\
\hline
\end{tabular}


As shown in Table 3, Flexitime working seems the easiest scheme to adopt. Compressed hours, short-period break, and longer absence schemes are slightly easy to adopt in practice. An annualised-hours scheme is not easy but not hard to adopt. However, shift swapping and self-rostering schemes are stated as being quite difficult to adopt in practice.

\subsection{User competency}

As indicated in a 2006 UK Government Report, user competency can be used to imply an opportunity to move on to the highest flexible working practice (NAO, 2006). To investigate this issue in the current research, the experienced ICT management respondents were asked to provide their opinions towards the current situation of user competency on a particular ICT service available at present. As shown in Table 4, ICT services in SLAs may include E-mail, local intranet, internet access, wired telephone, Voice over Internet Protocol (VoIP), remote access system, video conferencing, wireless devices, and wireless LAN. Level of user competency, which respondents have given is indicated on a scale of $1-5$ as [1] service is not available, [2] service is competently used by less than $20 \%$ of all users, [3] service is competently used by between $21 \%$ - $50 \%$ of all users, [4] service is competently used by between $51 \%$ - $80 \%$ of all users, and [5] service is competently used by most users.

Table 3. Adoptability degree of flexible working schemes

\begin{tabular}{lllllllll}
\hline Working Scheme & Count & Max & Min & Mean & Median & Mode & Variance & Std. Deviation \\
\hline Flexitime working & 7 & 5 & 5 & 5.00 & 5.00 & 5 & 0.00 & 0.00 \\
Compressed hours & 7 & 5 & 3 & 4.33 & 4.50 & 5 & 0.67 & 0.82 \\
Short-period break & 7 & 5 & 3 & 4.00 & 4.00 & 3 & 1.20 & 1.10 \\
Longer absence & 7 & 5 & 3 & 3.50 & 3.00 & 3 & 0.70 & 0.84 \\
Annualised hours & 7 & 5 & 1 & 2.83 & 3.00 & 1 & 2.57 & 1.60 \\
Shift swapping & 7 & 4 & 1 & 2.00 & 1.50 & 1 & 1.60 & 1.26 \\
Self-rostering & 7 & 3 & 1 & 1.67 & 1.00 & 1 & 1.07 & 1.03 \\
\hline
\end{tabular}

Table 4. ICT users competency

\begin{tabular}{lllllllll}
\hline ICT service & Count & Max & Min & Mean & Median & Mode & Variance & Std. Deviation \\
\hline E-mail & 9 & 5 & 5 & 5.00 & 5.00 & 5 & 0.00 & 0.00 \\
Local intranet & 9 & 5 & 1 & 4.56 & 5.00 & 5 & 1.78 & 1.33 \\
Access to internet & 9 & 5 & 3 & 4.33 & 5.00 & 5 & 0.75 & 0.87 \\
Wired telephone & 9 & 5 & 1 & 4.11 & 5.00 & 5 & 3.11 & 1.76 \\
Voice over Internet & 9 & 5 & 1 & 3.00 & 2.00 & 2 & 2.50 & 1.58 \\
Protocol (VoIP) & & & & & & & & \\
Remote access ICT system & 9 & 5 & 2 & 2.56 & 2.00 & 2 & 1.28 & 1.13 \\
Video conferencing & 9 & 5 & 1 & 2.22 & 2.00 & 1 & 2.19 & 1.48 \\
Wireless devices & 9 & 4 & 1 & 2.11 & 2.00 & 2 & 0.86 & 0.93 \\
Wireless LAN & 9 & 4 & 1 & 1.78 & 1.00 & 1 & 1.19 & 1.09 \\
\hline
\end{tabular}


The results show that the services competently used by most users are mainly fixedline-access services, which are E-mail, local intranet, internet access, and wired telephone. Nonetheless, wireless ICT services are competently used by a small number of users at present. As indicated by a UK Government Report, user knowledge is one of barriers to the higher flexible working stage (NAO, 2006; Gibson and Luck, 2004).

\subsection{Alternative workplace}

Provision of an alternative workplace reflects an opportunity for staff to choose their workplace more independently. However, it depends on ICT services providing suitable services to staff in each alternative workplace (Gibson and Luck, 2004). ICT management respondents were asked to provide information on their SLAs current ICT services, in terms of level of accessibility from a distance. As shown in Table 5, alternative workplaces for SLA staff may include head-, satellite-, home, guest- and instant offices. The accessibility level of ICT services and organization data, which respondents gave, was indicated on a scale of 1-5 as [1] ICT service is not available, [2] Basic ICT service is provided, [3] Basic ICT service and departmental data are provided, [4] Most ICT service and organisational data are provided, and [5] All ICT service and organisational data are provided.
As shown in Table 5, most ICT services and organisational data can be provided only at the SLA's premises (e.g. head- and satelliteoffices). At home office, staff can access only their departmental data and basic ICT services. It means that staff may be able to perform only general work from home. At guest and instant offices, only basic ICT services, such as E-mail, are provided to staff. This indicates a limitation of flexible working at alternative workplaces. It seems that staff are not indirectly encouraged to choose independently an alternative workplace.

\subsection{Implementation of alternative working policy}

Alternative working policy, such as home/ remote working, may enable staff to work more flexibly than under the current working policy (DfEE, 2000). Moreover, the policy may assist the organisation to achieve a higher level of occupation efficiency, for example when some working areas can be let to others (Gibson and Lizieri, 1999). To investigate the current policy direction, the property/estate/asset management respondents were asked to provide information on the implementation of alternative working policies. As shown in Table 6, alternative working policy may include satellite office, part-time home/remote working, unreservable hotdesking, informal meeting area, reservable hotdesking, full-time home/remote working, quiet personal working area, space

Table 5. Accessibility of ICT services and organisation data

\begin{tabular}{lllllllll}
\hline Working place & Count & Max & Min & Mean & Median & Mode & Variance & Std. Deviation \\
\hline Head office & 9 & 5 & 3 & 4.56 & 5.00 & 5 & 0.53 & 0.73 \\
Satellite office & 9 & 5 & 3 & 4.33 & 4.00 & 4 & 0.50 & 0.71 \\
Home office & 9 & 4 & 2 & 3.11 & 3.00 & 3 & 0.61 & 0.78 \\
Guest office & 9 & 3 & 1 & 2.00 & 2.00 & 1 & 0.75 & 0.87 \\
Instant office & 9 & 3 & 1 & 1.67 & 2.00 & 1 & 0.50 & 0.71 \\
\hline
\end{tabular}


Table 6. Implementation of altenative working policy

\begin{tabular}{|c|c|c|c|c|c|c|c|c|}
\hline Working policy & Count & Max & Min & Mean & Median & Mode & Variance & Std. Deviation \\
\hline Satellite office & 5 & 5 & 1 & 3.60 & 5.00 & 5 & 3.80 & 1.95 \\
\hline $\begin{array}{l}\text { Part-time home/remote } \\
\text { working }\end{array}$ & 5 & 4 & 2 & 3.40 & 4.00 & 4 & 0.80 & 0.89 \\
\hline Unreservable hotdesking & 5 & 5 & 1 & 3.40 & 4.00 & 5 & 3.30 & 1.82 \\
\hline $\begin{array}{l}\text { Informal meeting area } \\
\text { for staff }\end{array}$ & 5 & 5 & 1 & 3.40 & 4.00 & 5 & 3.30 & 1.82 \\
\hline Reservable hotdesking & 5 & 5 & 1 & 3.20 & 4.00 & 4 & 2.70 & 1.64 \\
\hline $\begin{array}{l}\text { Full-time home/remote } \\
\text { working }\end{array}$ & 5 & 4 & 2 & 2.60 & 2.00 & 2 & 0.80 & 0.89 \\
\hline Quiet personal working & 5 & 5 & 1 & 2.60 & 2.00 & 2 & 2.30 & 1.52 \\
\hline $\begin{array}{l}\text { Shared space w/other } \\
\text { organisation }\end{array}$ & 5 & 3 & 1 & 1.60 & 1.00 & 1 & 0.80 & 0.89 \\
\hline Temporary rentable space & 5 & 2 & 1 & 1.60 & 2.00 & 2 & 0.30 & 0.55 \\
\hline
\end{tabular}

sharing, and rentable working area. Level of implementation of the alternative working policies, which respondents have given, can be indicated as [1] a policy is not appropriate for SLA office, [2] a policy may be appropriate but cannot identify whether it will be implemented, [3] a policy will be implemented in the near future, [4] a policy is being implemented, and [5] a policy is implemented.

A mean score of each alternative working policy is ranged between 1 and 5. According to property/estate/asset management's point of view, the highest score, satellite office, is being implemented by SLAs. This policy enables staff to work in different SLA's workplaces. Distant working policies, such as part-time home/remote working and full-time home/remote working policies, are being considered for adoption in the near future. According to alternative workspaces within SLA's office, unreservable hotdesking, informal meeting area, reservable hotdesking, and quiet personal working room policies are also being considered for adoption in the near future. However, the policies reflecting the financial flexibility, such as sharing workspace and temporary rentable area, are not being considered for adoption at present.

\section{DATA ANALYSIS}

\subsection{Non-territorial working environment}

According to the results shown in Table 1, the highest scoring problems are 'staff resistance' and 'cultural change problems'. 'Unsuitable management system' has been proposed by a small number of respondents. When compared to the proposed benefits, the frequencies of potential problems being stated are higher than the frequencies of potential benefits. It may be implied that non-territorial may be an inappropriate working environment for most respondents at present.

To find out whether the results can be representative for all management areas, a statistical analysis of the above data was undertaken. Since the data is not normally distributed, the Kruskal Wallis Test was used for testing this non-parametric data (Field, 2005; Black, 1994). As shown in Table 7, the data of potential benefits and problems was ranked and a calculated mean rank of each group was undertaken (Property, ICT, and HR).

After that, the data for each potential benefit/problems was calculated using its sum of ranks, based on the Chi-Square distribution. 
Table 7. Mean rank for Kruskal Wallis Test of Non-territorial working environment

\begin{tabular}{llll}
\hline & Position viewpoint & N & Mean rank \\
\hline \multirow{2}{*}{ Staff satisfaction } & Property/Asset/Estate & 6 & 10.0 \\
& Information \& Communication Technology & 8 & 10.0 \\
& Human resource & 6 & 11.7 \\
Better organisational culture & Property/Asset/Estate & 6 & 10.0 \\
& Information \& Communication Technology & 8 & 11.3 \\
& Human resource & 6 & 10.0 \\
Better work performance & Property/Asset/Estate & 6 & 10.7 \\
& Information \& Communication Technology & 8 & 11.5 \\
& Human resource & 6 & 9.0 \\
Staff resistance & Property/Asset/Estate & 6 & 10.8 \\
& Information \& Communication Technology & 8 & 10.0 \\
& Human resource & 6 & 10.8 \\
Cultural change challenge & Property/Asset/Estate & 6 & 10.8 \\
& Information \& Communication Technology & 8 & 10.0 \\
& Human resource & 6 & 10.8 \\
Unsuitable management system & Property/Asset/Estate & 6 & 12.3 \\
& Information \& Communication Technology & 8 & 9.0
\end{tabular}

The sum of ranks, $\mathrm{H}$, can be calculated from:

$$
\mathrm{H}=\frac{12}{N(N+1)} \sum_{i=1}^{k} \frac{R_{i}^{2}}{n_{i}}-3(N+1)
$$

where: $N$ is the total sample size; $n$ is the sample size of a particular group; $R_{i}$ is the sum of ranks of each group, and $k$ is the number of group.

As shown in Table 8, the sum of ranks $(\mathrm{H})$ of each potential benefits/problems can be displayed in the 'Chi-Square' column. Each H value was used to evaluate its significance of mean comparison. Where degree of freedom (df) is 2 , the asymptotic significant value of each potential benefit/problem is more than 0.05 as well as the significant value estimated by Monte Carlo simulation. Since the analysis shows that there is no significant difference of means amongst property, ICT, and HR management areas, the potential benefits/problems presented in the data above can be a representative for all the management areas.

\subsection{Monitoring flexible working staff}

According to the results in Table 2, 'Measurable target and output' is distinctively different from the others. 'Working-time tracking system' is the second highest mean score. However, 'trust based working' and 'occasional meeting' are infrequently proposed by respondents. A very high frequency of 'Measurable target and output' reflects a strong opinion of respondents that flexible working staff are likely to be effectively monitored and managed using this method.

To find out whether the data can be representative for all management areas, a statistical analysis of the above data was undertaken. Since the data is not normally distributed, the Kruskal Wallis Test was used for testing this non-parametric data (Field, 2005; Black, 1994). As shown in Table 9, the data of proposed measures was ranked and a calculated mean rank of each group was undertaken (Property, ICT, and HR). 
Table 8. Kruskal Wallis Test of Non-territorial working environment

\begin{tabular}{|c|c|c|c|c|c|c|}
\hline \multirow[t]{3}{*}{ Test statistics (b,c) } & \multirow[t]{3}{*}{ Chi-Square $[\mathrm{H}]$} & \multirow[t]{3}{*}{$\mathrm{df}$} & \multirow{3}{*}{$\begin{array}{l}\text { Asymp. } \\
\text { Sig. }\end{array}$} & \multicolumn{3}{|c|}{ Monte Carlo Sig. } \\
\hline & & & & \multirow[t]{2}{*}{ Sig. } & \multicolumn{2}{|c|}{ 99\% Confidence interval } \\
\hline & & & & & Lower bound & Upper bound \\
\hline Staff satisfaction & 2.33 & 2 & 0.31 & 0.61 (a) & 0.59 & 0.62 \\
\hline Better organisational culture & 1.50 & 2 & 0.47 & $1.00(\mathrm{a})$ & 1.00 & 1.00 \\
\hline Better work performance & 1.61 & 2 & 0.45 & 0.75 (a) & 0.74 & 0.76 \\
\hline Staff resistance & 0.15 & 2 & 0.93 & $1.00(\mathrm{a})$ & 1.00 & 1.00 \\
\hline Cultural change challenge & 0.15 & 2 & 0.93 & 1.00 (a) & 1.00 & 1.00 \\
\hline Unsuitable management system & 2.86 & 2 & 0.24 & 0.25 (a) & 0.24 & 0.26 \\
\hline
\end{tabular}

(a) Based on 10000 sampled tables with starting seed 1131884899; (b) Kruskal Wallis Test;

(c) Grouping variable: Position viewpoint

Table 9. Mean rank for Kruskal Wallis Test of monitoring flexible working staff

\begin{tabular}{llll}
\hline Proposed measures & Position viewpoint & N & Mean rank \\
\hline \multirow{2}{*}{ Trust based working } & Property/Asset/Estate & 6 & 8.5 \\
& Information \& Communication Technology & 8 & 11.0 \\
& Human resource & 6 & 11.8 \\
Measurable target and output & Property/Asset/Estate & 6 & 10.8 \\
& Information \& Communication Technology & 8 & 10.0 \\
& Human resource & 6 & 10.8 \\
Working-time tracking system & Property/Asset/Estate & 6 & 9.8 \\
& Information \& Communication Technology & 8 & 10.3 \\
& Human resource & 6 & 11.5 \\
Occasional meeting & Property/Asset/Estate & 6 & 10.7 \\
& Information \& Communication Technology & 8 & 11.5 \\
& Human resource & 6 & 9.0 \\
\hline
\end{tabular}

After that, the data of each measure was calculated its sum of ranks, based on the ChiSquare distribution. The sum of ranks, H, can be calculated from equation (1). As shown in Table 10, the sum of ranks $(\mathrm{H})$ of each potential benefits/problems can be displayed in the 'Chi-Square' column. Each $\mathrm{H}$ value was orderly used to evaluate its significance of mean comparison. Where degree of freedom (df) is 2 , the asymptotic significant value of each time spending area is more than 0.05 as well as the significant value estimated by Monte Carlo simulation. Since the analysis shows that there is no significant difference of means amongst property, ICT, and HR management areas, so that, the measures presented in the bar chart above can be a representative for the management areas. 
Table 10. Kruskal Wallis Test of monitoring flexible working staff

\begin{tabular}{|c|c|c|c|c|c|c|}
\hline \multirow{3}{*}{ Test statistics (b,c) } & \multirow{3}{*}{ Chi-Square $[\mathrm{H}]$} & \multirow[t]{3}{*}{$\mathrm{df}$} & \multirow{3}{*}{$\begin{array}{l}\text { Asymp. } \\
\text { Sig. }\end{array}$} & \multicolumn{3}{|c|}{ Monte Carlo Sig. } \\
\hline & & & & \multirow[t]{2}{*}{ Sig. } & \multicolumn{2}{|c|}{ 99\% Confidence interval } \\
\hline & & & & & Lower bound & Upper bound \\
\hline Trust based working & 2.18 & 2 & 0.34 & 0.49 (a) & 0.48 & 0.50 \\
\hline Measurable target and output & 0.20 & 2 & 0.91 & 1.00 (a) & 1.00 & 1.00 \\
\hline Working-time tracking system & 0.36 & 2 & 0.83 & $1.00(\mathrm{a})$ & 1.00 & 1.00 \\
\hline Occasional meeting & 1.61 & 2 & 0.45 & 0.74 (a) & 0.73 & 0.76 \\
\hline
\end{tabular}

(a) Based on 10000 sampled tables with starting seed 1201206483; (b) Kruskal Wallis Test;

(c) Grouping variable: Position viewpoint

\section{DISCUSSION}

Based on the flexible working evolution stages (Gibson and Luck, 2004) and the current research findings, Figure 3 presents essential flexible working applications in evolution stages within the context of public offices like SLA. Although a flexitime working scheme may be available to most staff in SLAs at present, a wider range of flexible working schemes should be considered and provided to staff to enable them to have the most suitable working and family life. When the organisation is moving to the open-plan working environment (Stage 2), providing a wider range of flexible working schemes (e.g. compressed hours and short-period break) may help the organisation to manage their working area more effectively. In the latter part of the open-plan stage, adopting longer absence and annualised hours schemes may increase flexibility of the working area to the higher level (Stage 3). Finally, prior to take-up of the higher stages (Stages 4 and 5), which enable staff to work more independently and flexibly, self-rostering and shift swapping may be suitable for staff that need high flexibility in their working time and place.

In parallel, where a wider range of flexible working schemes is being adopted, a broad range of ICT services directly supporting the higher flexible working environment should also be provided as common facilities where appropriate. ICT services of local intranet and internet access should be available for supporting staff working in the different organisation premises (e.g. satellite office). Moreover, when staff can work from home/remote places and/or independently relocate within the office premises, remote access system and Voice over Internet Protocol (VoIP) may be suitable ICT services supporting this flexible working stage. Finally, when the organisation is going to adopt the policy of distance working (guest and instant offices) and staff need more mobility in their workplace, wireless LAN and video conference system should be promoted where the security of the ICT can be maintained. Training in use of modern ICT for staff can be useful in assisting the organisation to overcome the user competency problem.

Where flexible working schemes and appropriate ICT services are in place, providing a wider range of alternative working policies is crucial for stepping up to the higher flexible working stages. According to the current survey results, satellite offices may be the easiest policy for SLAs to take-up. When working schemes and ICT services can securely promote the higher flexible working environment, the alternative working policies (e.g. unreservable/ reservable hotdesking, informal meeting area, and part-time home/remote working) should be available to staff for planning their working time and place more suitably and effectively. 


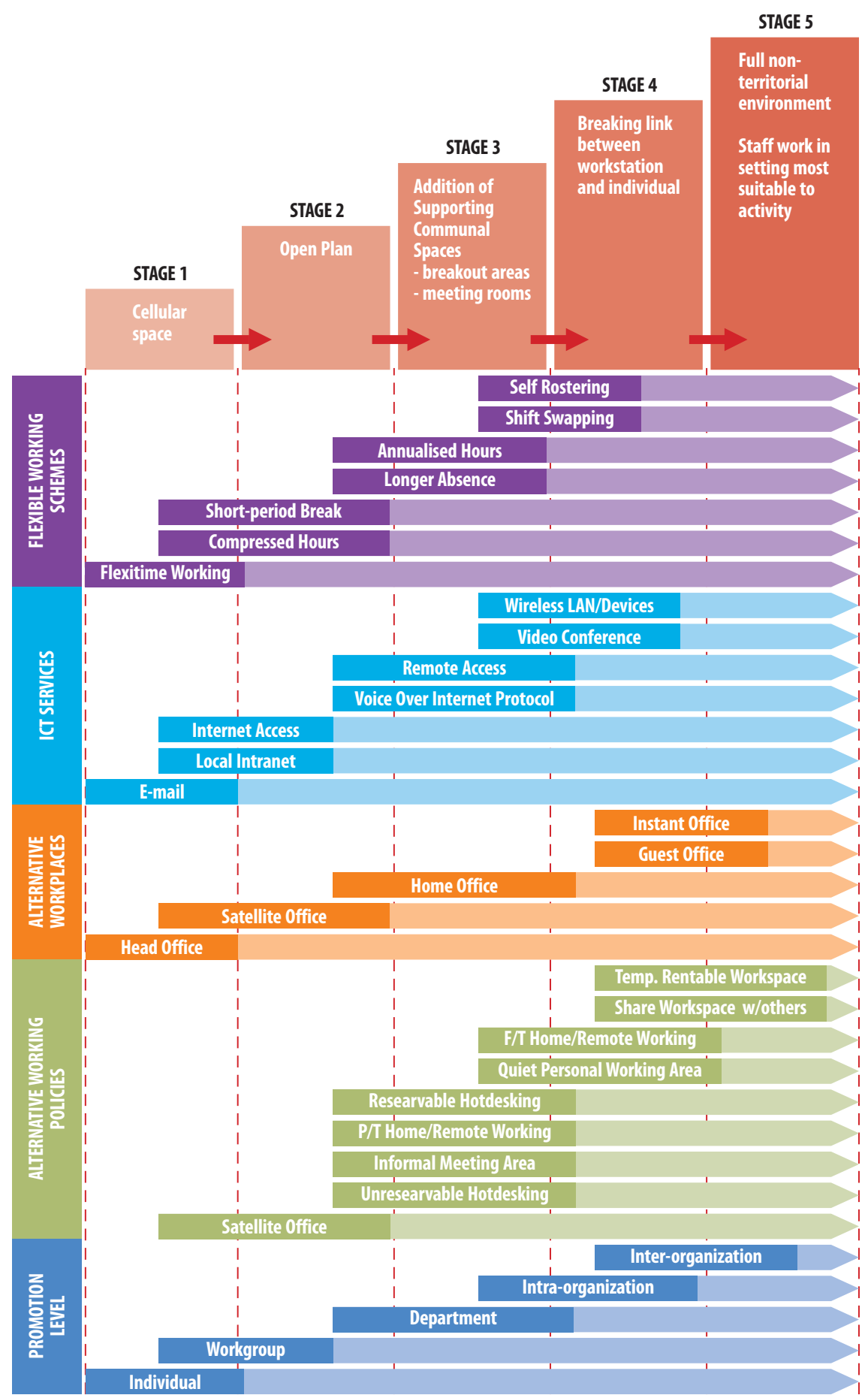

Figure 3. Proposed applications for evolution stages (adapted from Gibson and Luck, 2004) 
Moreover, when staff can plan their working time and place themselves, full-time home/ remote working policy and quiet personal working area may be provided to suit staff working activities. Finally, when the organisation is going to adopt the highest flexible working stage, temporary rentable workspace and inter-organisation workspace sharing policies should be promoted to increase the flexibility level of both the organisation and the property management practice.

Regarding the 'non-territorial working environment', some respondents, who currently have experience of flexible working, reacted positively towards it. However, most respondents having less or no experience of flexible working voiced their concerns and suggested potential problems, such as cultural change, staff resistance and unsuitable management system. This may indicate that the highest flexible working stage should be carefully promoted and implemented in practice, where the right perception towards the flexible working culture needs to be promoted. To prevent the cultural change problem, the proposed application may be implemented in a bottom-up route or from the smaller to the bigger unit. For example, individual, workgroup, department, intra-organisation, inter-organisation levels, depending on the improvement of staff perception towards high flexible working culture.

More suggestions for promoting the right perception towards the flexible working culture in public offices are also described below (Gibson and Luck, 2004; NAO, 2006):

- Promoting activity based workspace on the basis of working environment suitability;

- Supporting staff to acknowledge the different behaviour in different environment;

- Promoting a variety of contracts depending on geographic location of the organisational office;
- Provide adequate ICT, HR and workspace management support for remote/ home working staff;

- Promoting good practice of working in open plan space;

- Promoting benefits of sharing space, workstation and managing the perceived 'loss of status';

- Training staff and managers to perform their work in different working environments;

- Training for managers dealing with remote/home working staff.

According to the current survey results, although the proposed measure - 'measurable target and output', is not currently adopted in all SLAs, experienced management have stated that the measure is likely to be an effective tool for monitoring flexible working staff when their organisations fully adopt flexible working.

\section{CONCLUSIONS}

The highest flexible working environment is acknowledged as a working environment providing the most suitable working time and place for everyone in an organisation. However, the concept may not be implementable at present in SLAs because of the problems of cultural change and inadequate support from the current organisational policy/regulation.

To move on to the higher flexible working stage, readiness for the main components of flexible working is important. Promoting the right support in the evolution of flexible working is necessary for an organisation wishing to take-up flexible working in practice. Promoting the best practice and encouraging staff to perceive the benefits of flexible working by level of adoption, including individual, workgroup, department, intra-, and inter-organisation, is a crucial step for minimising potential problems, such as discontent of staff, cultural change effects, and unsuitable management system. 
Theoretically, where applications of the three components, property, ICT and HR, can be fully promoted and implemented in practice, both the organisation and the individual may gain maximum benefits, in terms of effective resource management and work-life balance.

\section{LIMITATIONS AND RECOMMENDATIONS}

As this research is based on a limited sample size, the research outcomes may be used to mainly explain the characteristics of SLAs. However, the research outcomes may be applied to a particular organisation having similar characteristics to the sample.

Although this research provides important insights into how SLAs can achieve the highest flexible working environment, the application of the three components in each flexible working evolution stage need to be further investigated, in terms of applicability and adoptability. Moreover, the legislation and organisation rules influencing flexible working in practice should be considered and improved by both Government and the Local Authorities. Changing the ways in which people work needs the right strategy and timescale. Therefore, to achieve the best take-up of flexible working in practice, further research into this area needs to be done.

\section{REFERENCES}

Ackers, P. (2003) The work-life balance from the perspective of economic policy actors, Social Policy \& Society, 2(3), pp. 221-229.

Audit Commission (1988a) Local Authority Property: A Management Overview. London: HMSO.

Audit Commission (1988b) Local Authority Property: A Management Handbook. London: HMSO.

Audit Commission (2000) Hot Property: Getting the best from local authority assets. London: the Audit Commission for Local Authorities and the National Health Service in England and Wales.
Black, K. (1994) Business Statistics: Contemporary Decision Making. New York: West Publishing.

Bryman, A. (2004) Social Research Methods. $2^{\text {nd }}$ ed. New York: Oxford University Press.

Burchell, B.J., Day, D., Hudson, M., Ladipo, D., Mankelow, R., Nolan, J.P., Reed, H., Ines C Wichert, I.C. and Wilkinson, F. (1999) Job Insecurity and Working Intensification: Flexibility and the Changing Boundaries of Work. York: Joseph Rowntree Foundation.

Clark, S. (2000) Work-family border theory: a new theory of work-life balance, Human Relations, 53(6), pp. 747-770.

Dawson, C. (2006) A Practical Guide to Research Methods: A user-friendly manual for mastering research techniques and projects. $2^{\text {nd }} \mathrm{ed}$. Oxford: How to Books.

Dettwiler, P. (2008) Modelling the relationship between business cycles and office location: The growth firms, Facilities, 26(3/4), pp. 157-172.

DfEE (2000) Work-life balance: Changing Patterns in a changing world. London: Department for Education and Employment.

Dillman, D.A., Eltinge, J.L., Groves, R.M., and Little, R.J.A. (2002) Survey Nonresponses in design, data collection, and analysis. In: Groves, R.M., Dillman, D.A., Eltinge, J.L., and Little, R.J.A. eds. Survey Nonresponse. New York: John Wiley \& Sons.

Dixon, T. (2005) The impact of information and communications technology on commercial real estate in the new economy, Journal of Property Investment and Finance, 23(6), pp. 480-493.

Field, A. (2005) Discovering Statistics: Using SPSS. $2^{\text {nd }}$ ed. London: SAGE.

Gershon, P., Sir (2004) Releasing resources to the front line: Independent Review of Public Sector Efficiency. London: HMSO.

Gibson, V. and Hedley, C. (1999) Property Information and Performance Measurement: A Study of Current Practice in Corporate Property Management, Cutting Edge 1999: Proceedings of the Property Research Conference of the RICS, Cambridge, 6th -7th September 1999.

Gibson, V. and Lizieri, C. (1999) New Business practices and the corporate real estate portfolio: how responsive is the UK property market? Journal of Property Research, 16(3), pp. 201-218.

Gibson, V. and Luck, R. (2004) Flexible working in Central Government: Leverage the benefit. London: Office of Government Commerce. 
Gibson, V. and Luck, R. (2006) Longitudinal analysis of corporate real estate practice changes in CRE strategy policies, functions and activities, Facilities, 24(3/4), pp. 74-89.

Hurme, P. (2005) Mobile communication and work practices in knowledge-based organizations, $A n$ Interdisciplinary Journal on Humans in ICT Environments, 1(1), pp. 101-108.

Khamkanya, T. and Sloan, B. (2008) Flexible working in Scottish Local Authority Property: Developing a Combined Resource Management Strategy, International Journal of Strategic Property Management, 12(3), pp. 183-202.

Kirkwood, J.S. (1994) Network technology: electronic mail, discussion lists and anonymous FTP for property management, Property Management, 12(3), pp. 33-38.

Kirkwood, J.S. (1995) Network technology: potential applications within facilities management, $\mathrm{Fa}$ cilities, 13(11), pp. 8-12.

Laing, A., Duffy, F., Jaunzens, D. and Willis, S. (1998) New Environments for Working: The Redesign of Offices and Environmental Systems for New Ways for Working. London: Taylor \& Francis.
Lyons, M., Sir (2004) Towards Better Management of Public Sector Assets: A Report to the Chancellor of the Exchequer London: HMSO.

McGregor, W. (2000) The future of workspace management, Facilities, 18(3/4), pp. 138-143.

NAO (2006) Getting the best from public sector office accommodation. London: National Audit Office Press Office.

Nenonen, S. (2004) Analysis the intangible benefits of work space, Facilities, 22(9/10), pp. 233-239.

Rowlatt, A., Clayton, T. and Vaze, P. (2002) Where, and how, to look for the New Economy, Economic Trends, No. 580, pp. 29-35.

Sullivan, K. (1996) Changing technology and forecasting office space requirements, Property Management, 14(1), pp. 24-29.

Ward, V. and Holtman, C. (2000) The role of private and public spaces in knowledge management. Proceedings of the BPRC Conference on Knowledge Management: Concepts and Controversies, 10-11 February 2000. Coventry: Warwick University.

\section{SANTRAUKA}

\section{LANKSTUS DARBAS ŠKOTIJOS VIETOS VALDŽIOS POŽIŪRIU: PEREINAME PRIE AUKŠČIAUSIO LANKSTUMO LYGIO}

\section{Thadsin KHAMKANYA, Brian SLOAN}

Lankstus darbas atsirado kaip modernus, veiksmingas ir ekonomiškas biuro išteklių valdymo būdas. Aukščiausio lygio lankstaus darbo aplinka, ne teritorinè darbo aplinka, gali suteikti geriausių galimybių organizacijoms valdyti savo biurus daug efektyviau. Dar daugiau, biuro darbuotojai gali dirbti tinkamiausiu laiku ir tinkamiausiose jiems vietose. Tačiau valstybinès isstaigos, pavyzdžiui, Škotijos vietos valdžia, nelabai noriai priima lankstaus darbo koncepcija. Kultūros pokyčiai, neadekvačios aptarnavimo paslaugos, taip pat informacinès ir komunikacinès technologijos, darbo organizavimo schemos bei alternatyvaus darbo politika yra pagrindiniai lankstaus darbo koncepcijos taikymo barjerai. Norint îveikti šiuos barjerus, valstybinès institucijos turi strategiškai adekvačiai remti darbuotojus. Dar daugiau, lankstaus darbo kultūros rèmimas atitinkamais organizacijos lygmenimis gali būti gera kultūros pokyčiu problemų prevencijos strategija. 